\title{
Editorial
}

\section{Edição Especial UFPR}

Esta edição da InfoDesign reúne artigos submetidos, principalmente, por professores e estudantes vinculados ao Programa de Pósgraduação em Design da UFPR - o primeiro da área na região sul e o quinto stricto sensu do país - e aprovados pelo fluxo de avaliação da revista. Com temáticas que envolvem educação, tecnologia ou comunicação do Design da Informação, esperamos que essa consistente produção inspire publicações similares de outros programas de pós-graduação do Brasil.

Luciane Maria Fadel \& Arthur Stofella, ao estudarem o Design da Informação de quinze modelos conceituais de jogos sérios, descritos no artigo A representação gráfica de modelos conceituais de jogos sérios, constataram que a baixa qualidade gráfica desses artefatos dificulta a exploração de seu conteúdo.

Com interesse no pensamento visual de estudantes de design, Juliana Bueno narra no artigo É possível aperfeiçoar nosso pensamento visual? Uma experiência didática em graduação de Design Gráfico uma proposta didática que vem sendo aplicada no curso de Design Gráfico da UFPR para lecionar o assunto. Nas três edições realizadas, os estudantes demonstraram um aprimoramento nas representações gráficas feitas em sala de aula.

Bianca Mendes Rati \& Marcos Namba Beccari analisaram o discurso de gênero-neutro veiculados pelas marcas de cosméticos Simple Organic e Fluide Beauty à luz da filosofia de Foucault e da Teoria Queer no artigo Design gênero neutro: uma análise discursiva do design das marcas de cosméticos Simple Organic e Fluide. Os resultados apontam que o design empregado na duas marcas se encontram em direções opostas ao reproduzir ou questionar noções históricas de neutralidade.

Os autores do artigo "Deixe-me torná-lo meu": proposta de instrumento descritivo para mecanismos de personalização em interfaces digitais, Stephania Padovani \& Maicon Bernert Puppi, desenvolveram um instrumento voltado para a descrição de mecanismos de personalização em interfaces digitais por meio de uma metodologia que envolveu, entre outras etapas, revisão sistemática de literatura e consulta a especialistas.

O artigo Animações procedimentais em saúde: Proposta de Metodologia de Design para a Universidade Aberta do Sistema Único de Saúde/Universidade Federal do Maranhão, escrito por Carla G. Spinillo e mais quatro pesquisadoras, apresenta o estudo que desenvolveu a metodologia para design de Sequências Pictóricas de Procedimentos Animadas (SPPAs) - com etapas consecutivas de decupagem, 
representação e finalização - especificamente para a UNA-SUS/ UFMA.

Kelly Smythe, no artigo Caminhos para o fazer projetual no design de comunicação de risco, desenvolveu uma estrutura processual, após a análise de representações gráficas e discussões realizadas com alunos de graduação, para uso em projetos que abordam o design de comunicação de risco. Como resultado, a autora apresenta um processo que abarca três macro fases - pré-design, design e pós-design - subdivididas em etapas.

Isabella Aragão

Editora gerente 